\title{
Governance and Politics: Regulating Independence and Diversity in the Board Room
}

\author{
ØyVIND BøHREN AND R. ØySTEIn STRøM*
}

\begin{abstract}
This paper analyzes the economic rationale for board regulation in place and for introducing new regulation in the future. We relate the value of the firm to the use of employee directors, board independence, directors with multiple seats, and to gender diversity. Our evidence shows that the firm creates more value for its owners when the board has no employee directors, when its directors have strong links to other boards, and when gender diversity is low. We find no relationship between firm performance and board independence. These characteristics of value-creating boards support neither popular opinion nor the current politics of corporate governance.
\end{abstract}

Keywords: corporate governance, board composition, regulation

\section{INTRODUCTION}

The three fundamental concerns in board design are to align the interests of principals and agents, to provide information for monitoring and advice, and to foster decisionmaking effectiveness (Becht et al., 2003; and Hermalin and Weisbach, 2003). However, constructing aligned, informed, and decisive boards raises fundamental challenges. In particular, the task involves a wide set of board mechanisms, but existing theory and evidence cannot clearly tell how each mechanism interacts with the firm's behavior and performance. Thus, if regulators want to mandate or recommend board rooms with more independence, fewer men, more employees, or less busy directors, they must do this without knowing the impact of their actions on the firm's ability to create value. If anything, the academic literature questions the validity of the current regulatory

\footnotetext{
*The authors are respectively from the Norwegian School of Management (B1) and Oslo University College, Norway. This paper has benefited from comments by an anonymous referee, Paul André (associate editor), Marc Goergen, Paul Guest, Kartnik Krishnan, Bang Dang Nguyen, Øyvind Norli, Richard Priestley, Trond Randøy, David C. Smith, participants at the 2007 meetings of the European Finance Association in Ljubljana, the 6th European Workshop on Corporate Governance and Investment (Universitat de les Illes Balears), and the Workshop on the Politics of Corporate Governance (Copenhagen Business School). The authors acknowledge financial support from the Research Council of Norway (grant no. 154949/510) and data from Verdipapirsentralen ASA, the Oslo Stock Exchange, and the Centre for Corporate Governance Research. (Paper received May 2009, revised version accepted May 2010)
}

Address for correspondence: Øyvind Bøhren, Norwegian School of Management (BI), Nydalsveien 37, $\mathrm{N}-0442$ Oslo, Norway.

e-mail: oyvind.bohren@bi.no 
practice or has nothing to say about it. Becht et al. (2003) conclude their survey by stating that:

... formal analysis of the role of boards of directors and how they should be regulated is almost non-existent. ... In sum, the formal literature on boards is surprisingly thin, given the importance of the board of directors in policy debates.

Our paper addresses the politics of board design in an empirical setting which is particularly well suited for this purpose. First, the regulatory environment allows us to study the economic effect of a legal regime which is already in place. Mandatory employee directors represents such a context in our sample of Norwegian firms, which were subject to constitutional law on co-determination over the entire sample period 1989-2002.

Second, we analyze whether future regulation can be rationalized by how the board functions in the absence of regulation. This role is played by gender mix in the board room, director independence, and multiple directorships. These three board mechanisms were not regulated in the sample period, but were targeted two years after its end by a law for mandatory gender mix and a corporate governance code of the comply-or-explain type for independence and for multiple directorships. Thus, unlike for employee directors, we study these three board mechanisms not in order to measure the actual impact of a regulatory change. Rather, we explore whether the regulator could have used observable board characteristics in the unregulated period to motivate subsequent regulation. This is also why the sample period ends before the new regulation was passed, which happened in 2004.

This setting is particularly relevant for gender diversity, since Norway was the first country in the world to mandate this board characteristic. Moreover, the initiative was heavily sponsored by the Minister of Industry, who argued that making gender mix mandatory would increase firm value. ${ }^{1}$ Several European countries are currently in a similar situation. France has recently passed a law which will require $50 \%$ gender parity on the board of every public firm by 2015. Spain has introduced regulation of the comply-or-explain type for gender diversity, Italy and the Netherlands are contemplating similar measures, and the Tories consider making a similar move in the UK. ${ }^{2}$

Using a regulatory perspective, we study how these four board mechanisms (employee directors, gender mix, director independence, and multiple directorships) interact with firm value. Moreover, we control for the effect of other board mechanisms such as board size and insider ownership, of firm characteristics such as risk and unobservable fixed and random effects, of the general setting such as the industry, and of potential endogeneity between board mechanisms and firm value.

The existing politics of board design is heavily influenced by recent governance scandals, such as Ahold, Enron, Parmalat and Skandia. These events have produced a series of regulatory restrictions on the owners' control rights in the board room, such as the Sarbanes-Oxley Act in the US and new corporate governance codes in more than 50 countries. The problem is, however, that these attempts at avoiding what politicians

1 www.guardian.co.uk/business/2005/aug/10/workandcareers.genderissues.

2 See www.guardian.co.uk/world/2009/dec/02/french-government-gender-equality-plan for the French proposal, which was passed as law on December 4, 2009. The Spanish setting is described in www.20first.com/737-0-spanish-quota-does-not-take-hold.html, and www.economist.com/node/15661734? target=/ businessfinance/displayStory.cfm\&STORY_ID=15661734 comments on the situation in the Netherlands, Italy, and the UK. 
may consider the worst outcome (governance scandals) in a rather small number of firms may prevent owners from attaining their best outcome (maximum firm value) in the vast majority of firms, where governance breakdown is an improbable event. ${ }^{3}$ There are several good reasons for this suspicion. First, Hermalin and Weisbach (2006) show theoretically that board regulation in general can only improve welfare if there is either information asymmetry between the parties at the contracting stage, externalities to non-contracting parties, or if regulators have remedies that the contracting parties do not have. The authors do not think any of these conditions are met in practice. Second, the literature on specific board mechanisms lends little support to most regulatory interventions. Adams and Ferreira (2007) show theoretically that more independence reduces the board's information production, hurts its advisory role, and may also reduce its monitoring function. Consistent with this model, Bhagat and Black (1999) find no association between independence and performance in the US. Moreover, the evidence is sparse and inconclusive on the value of employee directors (Gorton and Schmid, 2000 and 2004; and Fauver and Fuerst, 2006) and gender mix (Carter et al., 2003; and Adams and Ferreira, 2009).

We improve on this situation in three ways. First, we focus on four board mechanisms that are often addressed by public policy. These mechanisms are employee directors, gender diversity, independence, and multiple directorships. As for employee directors, our sample firms are subject to a law which assigns one third of the board seats to the employees in firms that employ more than 200 people. Since only about $40 \%$ of our sample firms have employee directors, the resulting cross-sectional variation allows us to analyze the value effect of this mandatory rule, which has barely been addressed in the literature. ${ }^{4}$ The second unusual characteristic of the law is that the firm's CEO cannot be its chairman. ${ }^{5}$ Thus, CEO-chairman duality is not a shareholder decision in our sample firms, since the regulator mandates separation. Although not by law, it is also an empirical fact that managers other than the CEO are never directors in their firm. Even the CEO is not a member in two thirds of the sample firms. Thus, although the CEO is always present, he or she has no vote. This means that compared to the UK or the US, the boards we observe cannot formally be so strongly controlled by management.

Independence, multiple directorships, and gender diversity were heavily discussed publicly in the second half of our sample period. The general argument from those advocating regulation was that these board mechanisms were poorly designed. Two years after the final sample year, independence entered the governance code as a comply-or-explain rule, the code questioned the value of directors with many seats, and gender diversity was mandated by law. ${ }^{6}$ Our data set includes each director's gender, and we can estimate independence and director networks as specified by the theory.

3 'Indeed, reformers generally battle past scandals rather than future market failures, their main purpose being the short term rebuilding of investor confidence or the soothing of voter anger prior to the next election' (Hertig, 2005).

4 Firms in the newspaper, shipping, petroleum extraction, and financial service industries are exempted. $62 \%$ of the sample firms have more than 200 employees, and two thirds of these firms have employee directors.

5 The rule applies to firms with a share capital above NOK 3 mill ( 0.35 mill. euros), which means practically every listed firm.

6 A corporate governance code for public firms issued in 2004 recommends at least $50 \%$ independent directors and warns against busy directors. A law passed in the same year mandates at least $40 \%$ directors of each gender in all public firms from 2006 on. This final date of compliance with this law was later extended until year-end 2008. 
Hence, we can explore whether more independence, more directors with fewer seats, or more gender diversity have unexploited economic potential in the pre-regulation period that stockholders will not capture unless regulators mandate or encourage such changes.

Our second contribution is to develop new empirical proxies for board independence and for the network effect of multiple directorships. Existing board studies as well as current governance codes classify directors as dependent if they are affiliated, i.e., have past or present business or family relationships to the firm. According to the Hermalin and Weisbach (1998) model, however, affiliation is not what matters for independence. Rather, it is the relative timing of entry, i.e., whether the director was appointed before or after the current CEO took office. Thus, the existing studies may have failed to find a significant relationship between independence and performance because of a weak independence proxy. We explore this possibility by measuring independence according to the Hermalin and Weisbach logic, which we accomplish by following the same board over 14 years. Moreover, we construct a richer director network proxy than the measure used so far, which is simply the number of seats the director holds in other firms. This classic measure assumes every board seat is equally important as an information source. Moreover, it double-counts when more than one of the firm's directors sit on the same outside board. Our network proxy avoids this double-counting, and it treats each seat individually according to its information centrality. The measure accounts for the direct information effect of sitting on another firm's board, and also for the indirect effect of meeting directors on that board who hold seats in still other boards.

Finally, we account for board mechanisms that are not targeted by politics, but that may still matter for board quality, such as board size and insider ownership. Overall, we allow for the joint impact on firm value of three alignment mechanisms (insider ownership, outside ownership concentration, and director independence), four information mechanisms (director network, having the firm's CEO on the firms's board, on other firms' boards, and having other firms' CEO on the board), and four decisiveness mechanisms (board size, gender mix, age dispersion, and employee directors). We also allow for potential endogeneity between these mechanisms and performance. The sample is all non-financial firms listed on the Oslo Stock Exchange from 1989 to 2002. This panel allows us to account for unobserved determinants of firm value by means of fixed effects and random effects estimation, which is uncommon in the board literature. Our ownership data accounts for every equity holding by every owner in every firm at every year-end.

We find that the value of the firm is significantly higher when directors have wide networks through board seats they hold in other firms (the board is informed). Firms with less gender diversity and less employee directors create more value than others (the board is decisive). These relationships are statistically significant at standard levels, and the economic significance is strongest for the decisiveness mechanisms. In contrast, there is no evidence that independence relates systematically to performance. All these results are robust to a wide set of alternative econometric techniques, model specifications, and empirical proxies.

As for governance and politics, our findings are relevant both for board mechanisms that were regulated during the sample period (employee directors) and for mechanisms that were considered for regulation after the sample period ended (independence, multiple directorships, and gender diversity). Regarding regulation 
in place, the negative association between firm value and employee directors questions the claim that owners benefit from mandatory co-determination in the board room. The finding suggests there is an economic reason why owners do not voluntarily share their control rights with employees. In our setting, co-determination is constitutional law. Moreover, employees are not just on the supervisory board, like in Germany, but on the executive board as well.

The evidence lends no support to the idea that future board regulation can be rationalized economically by how the board functions in the absence of regulation. First, our findings reflect that good directors may be dependent on the CEO. This runs counter to conventional wisdom behind recent governance regulation, but is in line with theory and the existing evidence from the US. Notice also that our findings are not from a common law regime, and that we use a different independence measure than earlier studies. Still, we reproduce the old result. Taken together, this supports the view that owners do not need the regulator's assistance in order to trade off a director's role as hands-off monitor against the role as hands-on adviser. Stronger emphasis on independence may not just hurt the board's advice function. It may also reduce the value of monitoring, which is the board function that has received all the attention in public discussions of board independence.

Second, the lack of a positive relationship between firm value and gender mix in our unregulated sample period fails to produce economic arguments for encouraging or mandating more gender diversity in the board room. Finally, it seems most directors have multiple seats not because they elbow themselves into the board room and become overstretched. Rather, they are in demand by the owners due to the information network they bring along. Unlike earlier studies, which have produced mixed results, our findings are based on a measure that captures considerably wider network characteristics than just the number of seats held.

The rest of the paper is organized as follows. Section 2 presents the model, reviews the literature, and explains our methodology. Section 3 describes the institutional framework, the data selection procedure, and presents the descriptive statistics. We analyze the relationship between board design and firm value in Sections 4 and 5, while Section 6 concludes.

\section{THE MODEL}

We want to investigate the following relationship between the value of the firm, $V$, the board design mechanisms, and controls, where $i$ is the firm and $t$ is time:

$$
\begin{aligned}
V_{i t}= & \text { Constant }+\alpha_{1} \text { Insider ownership }_{i t}+\alpha_{2} \text { Ownership concentration }_{i t} \\
& +\alpha_{3} \text { Independence }_{i t}+\alpha_{4} \text { CEO director }_{i t}+\alpha_{5} \text { Exported CEO }_{i t} \\
& +\alpha_{6} \text { Imported CEO }_{i t}+\alpha_{7} \text { Network }_{i t}+\alpha_{8} \text { Size }_{i t}+\alpha_{9} \text { Gender }_{i t} \\
& +\alpha_{10} \text { Board age dispersion }_{i t}+\alpha_{11} \text { Fraction employee directors }_{i t} \\
& +\beta V_{i, t-1}+\gamma_{1} \text { Firm size }_{i t}+\gamma_{2} \text { Risk }_{i t}+u_{i t} .
\end{aligned}
$$

We organize the discussion of the model according to the three major concerns in board design, which are to align the interests of principals and agents (Section 2(i)), provide information for monitoring and support $(2(i i))$, and to enhance the board's effectiveness as a decision-maker $(2($ iii $))$. The empirical proxies are defined in Table 1. As shown by model (1) above, we analyze the role of board characteristics that are 
Table 1

The Empirical Proxies

\begin{tabular}{|c|c|}
\hline Variable & Definition \\
\hline \multicolumn{2}{|l|}{ Alignment } \\
\hline Insider ownership & Fraction of equity owned by the firm's officers and directors \\
\hline $\begin{array}{l}\text { Ownership } \\
\text { concentration }\end{array}$ & $\begin{array}{l}\text { The sum of squared equity fractions across all the firm's outside } \\
\text { owners (Herfindahl index) }\end{array}$ \\
\hline Independence & Board tenure minus CEO tenure \\
\hline Board tenure & $\begin{array}{l}\text { The average number of years since non-employee directors took } \\
\text { office }\end{array}$ \\
\hline CEO tenure & The number of years since the CEO took office \\
\hline Chair tenure & The number of years since the chairman took office \\
\hline \multicolumn{2}{|l|}{ Information } \\
\hline CEO director & $\begin{array}{l}\text { Dummy variable which equals } 1 \text { if the CEO is a member of his } \\
\text { company's board and zero otherwise }\end{array}$ \\
\hline Exported CEO & The number of outside directorships held by the firm's CEO \\
\hline Imported CEO & The proportion of CEOs from other companies on the board \\
\hline Outside directorships & A director's number of directorships outside the firm \\
\hline Network & $\begin{array}{l}\text { Non-CEO director information centrality measure as defined in } \\
\text { footnote } 11\end{array}$ \\
\hline \multicolumn{2}{|l|}{ Decisiveness } \\
\hline SizeAll & The number of directors \\
\hline Size & The number of non-employee directors \\
\hline GenderAll & The proportion of female directors \\
\hline Gender & The proportion of shareholder-elected female directors \\
\hline Board age dispersion & The standard deviation of director age \\
\hline $\begin{array}{l}\text { Number of employee } \\
\text { directors }\end{array}$ & The number of directors elected by and from the employees \\
\hline Employee directors & $\begin{array}{l}\text { The fraction of employe directors, measured as the number of } \\
\text { employee directors divided by the number of directors }\end{array}$ \\
\hline \multicolumn{2}{|l|}{ Controls } \\
\hline Firm size & The natural logarithm of sales revenue \\
\hline Risk & $\begin{array}{l}\text { The firm's equity beta, estimated by using daily stock returns data } \\
\text { over the past two years and the OSE total index as a proxy for } \\
\text { market returns }\end{array}$ \\
\hline Industry & The firm's 4-digit GICS code \\
\hline \multicolumn{2}{|l|}{ Performance } \\
\hline & Market value of assets divided by its book value (Tobin's $Q$ ) \\
\hline ROA & $\begin{array}{l}\text { Earnings from operations after taxes divided by the accounting } \\
\text { value of assets (Book return on assets) }\end{array}$ \\
\hline ROS & $\begin{array}{l}\text { Capital gains plus dividends divided by the stock's market value } \\
\text { (Market return on stock) }\end{array}$ \\
\hline
\end{tabular}

regulated in the sample period (employee directors) or that became regulated after the sample period ended (independence, multiple directorships, and gender mix). Simultaneously, we account for mechanisms that are not exposed to regulation neither inside nor outside the sample period, such as insider ownership and board size.

(i) Alignment

Interest alignment in a board context concerns the firm's ownership structure and the degree of independence between directors and officers. Shleifer and Vishny (1986) 
argue that the principal's incentives and power to monitor the agent increase with ownership concentration. Moreover, outside ownership concentration is less powerful than inside concentration, which is the more relevant characteristic in a board setting. Because inside owners may become entrenched, the expected relationship between ownership concentration and market value cannot be specified ex ante. ${ }^{7}$ We measure insider ownership by the aggregate equity fraction held by the firm's officers and directors as a group, and ownership concentration by the Herfindahl index based on all outside (i.e., non-insider) owners.

Most of the board literature and all the governance codes argue that monitoring quality improves with increasing independence between the monitoring officers and the monitored directors. This idea has received weak empirical support. Although Baysinger and Butler (1985) estimate a positive relationship between independence and performance, Hermalin and Weisbach (1991) find no significant link. The link is negative and significant in Yermack (1996), Agrawal and Knoeber (1996), Klein (1998) and Bhagat and Black (1999 and 2002).

This inconsistency may have occurred because the affiliation-based independence measures used so far (Byrd and Hickman, 1992) are not derived from a formal behavioral theory. Therefore, we measure independence based on the Hermalin and Weisbach (1998) model, where the CEO's ability to recruit dependent directors increases with the firm's past performance. This theory predicts that the longer the history of good performance under the current CEO, the less independent the board. Thus, the key independence criterion is not affiliation, but whether the director was appointed before or after the current CEO took office. ${ }^{8}$ Consistent with this model, we measure board independence in firm $i$ as the difference between the average tenure of the board's non-CEO directors and the tenure of the CEO:

$$
\text { Independence }_{i} \equiv \frac{1}{n} \sum_{j=1}^{n} \text { Non-CEO director tenure }{ }_{i j}-\text { CEO tenure }{ }_{i}
$$

where Non-CEO director tenure ${ }_{i j}$ is the number of years since non-CEO director $j$ entered office in firm $i$, and $n$ is the number of shareholder-elected directors. According to Hermalin and Weisbach (1998), the board is more independent the higher the value of (2). ${ }^{9}$

Carter and Lorsch (2004) argue that board independence is driven by absolute tenure rather than relative, and that independence decreases rather than increases as director tenure grows. This happens because directors become emotionally more

7 A common way to account for this ambiguity is by adding quadratic ownership terms in the regression equation (McConnell and Servaes, 1990). Due to very strong collinearity between linear and quadratic terms in our data set, we ignore nonlinear ownership effects in (1), but account for it in the robustness checks.

8 A second reason for questioning the conventional independence proxy in our setting is the institutional framework. The CEO of our sample firms is also a director in just one third of the cases, the CEO cannot chair the board by law, and other members of the management team are never on the board. Thus, although most directors in our sample are independent in the Byrd-Hickman sense, they may not be so according to the Hermalin and Weisbach (1998) logic. Unfortunately, missing data on a director's affiliation to the firm beyond employment prevents us from also using the classic independence measure.

9 The CEO is never the chair and mostly not a voting board member in our sample firms. Still, we will argue in Section 2(ii) that the CEO's power in the board room may be less dependent on the right to vote than on the fact that the CEO is always present. The evidence in Section 4 supports this view. Moreover, the system of board committees had not yet been introduced in our sample period. Overall, this suggests that regardless of the CEO's formal power, longer tenure relative to the other board members may be a valid proxy for the CEO's ability to influence board independence. 
attached to the firm's management the longer the directors stay. Under this logic, a higher value of (2) due to the first term means less independence rather than more. However, (2) also reflects the tenure of the CEO by the second term, which is irrelevant under the Carter and Lorsch hypothesis. Hence, we alternatively use board tenure, CEO tenure, and also chair tenure as empirical proxies in the robustness tests.

There are good reasons to expect that a positive relationship between independence and firm value simply does not exist. Although directors provide both monitoring and advice, the Hermalin and Weisbach (1998) model only captures monitoring. Correspondingly, regulation mandating more independence misses the point that:

Inside directors are conflicted, but well informed. Independent directors are not conflicted, but are relatively ignorant about the company (Bhagat and Black, 1999, p. 264).

Adams and Ferreira (2007) formalize this insight by showing that if independent directors have stronger monitoring incentives than dependent directors, more independence may hurt the stockholders. This happens because the CEO responds to increased board independence by providing less information. In fact, the value of both monitoring and advice may decrease as independence grows. Thus, an inverse or no relationship between independence and firm value is consistent with a model that recognizes the conflict between monitoring and advice, and which lets information supply respond endogenously to independence.

\section{(ii) Information}

The value of the board's monitoring and advice functions depends on the quality of the information sources. Carter and Lorsch (2004) posit that since the CEO has superior information about the firm and its environment, he should be a fully voting member. In contrast, agency theory suggests that due to the value of independence, the CEO should not belong to a board which is supposed to monitor him. One may also argue that if the CEO's major role in the board is to produce information for monitoring and advice (Adams and Ferreira, 2007), what matters is presence rather than the right to vote. Because the CEO is always on the board but is a member in just one third of our sample firms, we can test these three competing predictions. This has apparently not been done in the literature so far. ${ }^{10}$

Whereas the agency logic suggests the CEO should pay full attention to his firm, the information perspective argues that the firm may benefit when the CEO is on other firms' boards. We use the exported CEO director variable to capture this characteristic (Perry and Peyer, 2005). Correspondingly, a CEO from another firm (imported CEO director) may have low value. This is both because he is already fully committed and because he has the same role in the principal-agent setting as the CEO he is supposed to monitor (Gilson and Kraakman, 1991). Again, the counterargument is the information idea that the imported CEO director brings new perspectives and makes every director better informed. The net impact of these alignment and information effects can only be determined empirically.

10 The CEO director mechanism may be classified under either the alignment or the information heading. We choose the latter, but with no implicit assumption about relative importance. 
Just like CEOs, non-CEO directors with multiple seats may bring back useful information for advice, but may also become overstretched monitors (Ferris et al., 2003; and Fich and Shivdasani, 2006). The latter effect is often a public concern. Fama (1980) argues that the average number of outside directorships held by the firm's directors reflects the value of their monitoring ability. This simple measure, which is predominant in finance-based board research, is potentially problematic. It ignores the uniqueness of each seat by not distinguishing between $n$ director links to just one other firm and one link per firm to $n$ different firms. It also neglects the indirect links created when the director joins a second firm's board with someone holding a seat in a third firm's board. We avoid both problems by applying an information centrality concept from social network analysis (Wasserman and Faust, 1994) which has recently been recommended for board research (Conyon and Muldoon, 2006). Our measure captures the firm's direct and indirect links to directors in other firms, treats each seat individually, and avoids double counting. The centrality score increases with the number of direct and indirect paths from our board to other boards. It is also higher the shorter the indirect path. ${ }^{11}$ When computing the centrality score, we include a given director's board seat in any other public firm, regardless of whether that firm is in our sample. The higher the board's centrality score, the stronger the predicted information effect of its directors' network.

\section{(iii) Decisiveness}

Decisiveness mechanisms influence the board's effectiveness as a decision-maker. Board size, director gender, director age, and employee directors are supposed to serve this function in our model. Yermack (1996) and Eisenberg et al. (1998) document that performance decreases with increasing board size. This is consistent with the hypothesis that unless new members bring new insights, larger boards both take longer time to decide and make more conventional decisions (Gjølberg and Nordhaug, 1996). This means the negative effect of longer decision time and stronger pressure on consensus must be traded off against the positive impact of a wider opportunity set generated by a more diverse board (Buchanan and Tullock, 1962). Therefore, the issue is not just whether board size grows, but whether it does by means of new directors who differ sufficiently from the existing ones. Gender and age are potential ways to create such diversity.

11 Network theory uses concepts such as nodes and lines. In our setting, a node is a firm, and a line between two firms represents a joint director in the two firms. We define geodesic $g_{j k}$ as the shortest path between two nodes $j$ and $k$, and $G$ as the total number of nodes. The node $i$ is designated as $n_{i}$. Using Wasserman and Faust (1994, p. 192-197), we construct our information centrality measure in the following way: Form the $G$ $\times G$ matrix $A$ with diagonal elements $a_{i i}=\left(1+\right.$ sum of values for all lines incident to $\left.n_{i}\right)$ and off-diagonal elements $a_{i j}$, where:

$$
a_{i j}= \begin{cases}0 & \text { if nodes } n_{i} \text { and } n_{j} \text { are not adjacent } \\ 1-x_{i j} & \text { if nodes } n_{i} \text { and } n_{j} \text { are adjacent }\end{cases}
$$

$x_{i j}$ is the value of the link from firm $n_{i}$ to firm $n_{j}$. The inverse of $A$, which is $C=A^{-1}$, has elements $\left\{c_{i j}\right\}$, where we define $T=\sum_{i=1}^{G} c_{i i}$ and $R=\sum_{j=1}^{G} c_{i j}$. The information centrality index for firm $n_{i}$ is:

$$
C_{i}\left(n_{i}\right)=\frac{1}{c_{i i}+(T-2 R) / G} .
$$

This index measures the information content in the paths that originate and end at a specific firm. 
The evidence on gender diversity is scant and conflicting. Shrader et al. (1997), Smith et al. (2006) and Adams and Ferreira (2009) document a negative relationship between female directors and firm value, whereas Carter et al. (2003) find the opposite. Unlike in our case, it was not an issue in these countries (Denmark and the US) to mandate gender diversity after the sample period based on the idea of a suboptimal gender mix within the sample period. Moreover, we control for a wider set of board mechanisms that may matter for the role of diversity, such as insider ownership and director network. We measure gender diversity by the fraction of stockholderelected female directors. As far as we know, age has not been studied in this setting. Our proxy for age diversity is the variance of the directors' age.

Employee directors may influence both the alignment, information, and decisiveness role of the board. Although the hold-up problem suggests that owners should share control with employees who invest in firm-specific human capital (Hansmann, 1996; and Becht et al., 2003), Williamson (1996) argues that since employees have a contractual claim, they should not be residual claimants as well. In particular, employees will defend their sunk human capital investments by opposing decisions which threaten their welfare. This is the alignment role of employee directorships. As for its informational role, one may argue that outside directors are better monitors when firm-internal information comes through several channels (Raheja, 2005). Therefore, employee directors should supplement the CEO as the directors' information source. Finally, employee directors may matter for decisiveness, as the conflict of interest between owners and employees may increase decision complexity and reduce decisionmaking effectiveness (Cadbury, 2002).

Most studies report a negative association between employee directors and owner wealth. FitzRoy and Kraft (1993), Schmid and Seger (1998) and Gorton and Schmid (2000 and 2004) find that German firms with employee directors are less profitable than other firms, whereas Fauver and Fuerst (2006) find the opposite. Falaye et al. (2006) show that Canadian firms where employees are both stockholders and directors spend less on new assets, take fewer risks, grow more slowly, create fewer new jobs, deviate more from value maximization, have more serious cash flow problems, and are less productive. We measure board-driven co-determination by the fraction of the firm's directors that are employed by the firm. Unlike in Germany, the constitution mandates co-determination, and employees are on both the supervisory board and the more important executive board. Unlike in the Canadian setting, the employee directors in our sample are not owners as well. Both features suggest that in our setting, employee directors have more power and stronger incentives to make decisions that benefit the employees at the expense of stockholders.

By removing employee directors from the proxies for the board's independence, age diversity, network, size, and gender mix, we avoid multicollinearity problems. Also, we make it easier to separate the effects of shareholder-elected directors from those of employee-elected directors. On the other hand, some predictions may not distinguish between director types, such as the relationship between board size and decisiveness. We account for this concern in the robustness tests by including employee directors in the proxies for board size and gender mix.

Our control variables are firm size and risk, which we measure by the log of sales revenues and the beta of equity, respectively. Firm size is included due to its consistent correlation with value creation in asset-pricing tests (Hawawini and Keim, 2000). We include risk to account for the impact of cash flow uncertainty on firm value. Since we 
use stock beta, this measure reflects the firm's business risk, financial risk, and also the potential disciplining effect of debt on management's discretion over free cash flow. Our base-case measure of value (performance) is Tobin's $Q$, which we operationalize as the market value of assets per unit book value. The market value of debt is set equal to its book value. In the robustness tests, we alternatively measure performance as accounting returns on assets and market returns on stock.

The endogeneity problem of most governance studies applies to our setting as well (Demsetz and Lehn, 1985). First, omitted variables such as corporate culture may drive both governance and performance (Cronqvist et al., 2009). Second, causation may run from firm value to board mechanisms (reverse causation), such as when performance drives independence in the Hermalin and Weisbach (1998) model. Finally, board mechanisms may be internally related, such as when information production responds to independence in the Adams and Ferreira (2007) model.

We try to reduce these problems in four ways. First, we use repeated observations of the same firm over time. Compared to using a cross-sectional sample, our approach increases the likelihood of revealing stable relationships, also in the presence of endogeneity. The panel structure also allows us to control for the effect of unobservable, firm-specific characteristics. This reduces the omitted-variables problem (Hsiao, 2003). Second, the reverse causation problem is mitigated by the regulatory fact that whereas board composition is elected early in the calendar year, we measure performance at the end of that year. Thus, the key independent variables are fixed before the dependent variable in calendar time. Third, by including lagged performance as an independent variable in (1), we allow for performance persistence and for feedback from past performance to current board composition (Wooldridge, 2002). Finally, corporate governance theory cannot offer a well-defined system of equations with performance and board mechanisms as alternative dependent and independent variables. Therefore, accounting for endogenity by estimating such a system suffers from the lack of valid instruments (Agrawal and Knoeber, 1996; Bhagat and Bolton, 2008; Coles et al., 2003; Larcker and Rusticus, 2007 and 2010; and Brown and Caylor, 2006 and 2009). We choose a more limited and common approach in the robustness section by using instrumental variables and two-stage least squares (2SLS).

\section{DESCRIPTIVE STATISTICS}

Our sample is all non-financial firms listed on the Oslo Stock Exchange (OSE) at year-end at least once over the period 1989-2002. ${ }^{12}$ To reduce censoring bias in the tenure measures of the independence proxy, we start collecting director data in 1986. The ownership structure data, which is supported by Verdipapirsentralen ASA (www.vps.no) covers every equity holding by every investor in every firm. The accounting data and the stock return data are from the Oslo Stock Exchange (www.oslobors.no), and the board data is provided by the Centre for Corporate Governance Research (www.bi.no/ccgr).

Table 2 summarizes key properties of the frequency distributions for each board design mechanism used in the regressions. The figures for the alignment mechanisms

12 The OSE had an aggregate market capitalization of 68 bill. USD equivalents by year-end 2002. This ranks the OSE sixteenth among the twenty-two European stock exchanges for which comparable data is available. During our sample period, the number of firms listed increases from 129 to 203, market capitalization grows by $8 \%$ per annum, and market liquidity, measured as transaction value over market value, increases from $52 \%$ in 1989 to $72 \%$ in 2002 (sources: www.oslobors.no and www.fibv.com). 
Table 2

Summary Statistics for Board Design Mechanisms, Control Variables, and Firm Value

\begin{tabular}{|c|c|c|c|c|c|c|}
\hline Variable & Mean & Stdev & Median & Min & $\operatorname{Max}$ & Obs \\
\hline \multicolumn{7}{|l|}{ Alignment } \\
\hline Insider ownership & 0.074 & 0.203 & 0.000 & 0.000 & 1.000 & 1,290 \\
\hline Ownership concentration & 0.131 & 0.149 & 0.073 & 0.002 & 0.927 & 1,290 \\
\hline Independence & -0.363 & 2.512 & 0.000 & -12.857 & 10.333 & 1,290 \\
\hline Board tenure & 2.449 & 1.846 & 2.000 & 0.000 & 11.500 & 1,290 \\
\hline CEO tenure & 2.813 & 2.732 & 2.000 & 0.000 & 16.000 & 1,290 \\
\hline Chair tenure & 2.435 & 2.649 & 2.000 & 0.000 & 16.000 & 1,290 \\
\hline \multicolumn{7}{|l|}{ Information } \\
\hline CEO director & 0.236 & 0.425 & 0.000 & 0.000 & 1.000 & 1,290 \\
\hline Exported CEO & 0.371 & 0.756 & 0.000 & 0.000 & 6.000 & 1,290 \\
\hline Imported CEO & 0.046 & 0.090 & 0.000 & 0.000 & 0.667 & 1,290 \\
\hline Outside directorships & 1.877 & 1.329 & 2.000 & 0.000 & 7.000 & 1,290 \\
\hline Network & 0.195 & 0.107 & 0.209 & -1.667 & 2.330 & 1,290 \\
\hline \multicolumn{7}{|l|}{ Decisiveness } \\
\hline SizeAll & 6.534 & 1.828 & 6.000 & 2.000 & 15.000 & 1,290 \\
\hline Size & 5.355 & 1.228 & 5.000 & 2.000 & 14.000 & 1,290 \\
\hline GenderAll & 0.049 & 0.092 & 0.000 & 0.000 & 0.500 & 1,290 \\
\hline Gender & 0.032 & 0.080 & 0.000 & 0.000 & 0.500 & 1,290 \\
\hline Board age dispersion & 8.131 & 3.043 & 7.894 & 0.600 & 21.900 & 1,290 \\
\hline $\begin{array}{l}\text { Number of employee } \\
\text { directors }\end{array}$ & 1.180 & 1.255 & 1.000 & 0.000 & 4.000 & 1,290 \\
\hline Employee directors & 0.153 & 0.160 & 0.125 & 0.000 & 0.500 & 1,290 \\
\hline \multicolumn{7}{|l|}{ Controls } \\
\hline Firm size & 13.419 & 1.901 & 13.179 & 5.366 & 22.732 & 1,290 \\
\hline Risk & 0.762 & 0.631 & 0.702 & -0.994 & 8.127 & 1,290 \\
\hline \multicolumn{7}{|l|}{ Firm value } \\
\hline Q & 1.428 & 1.019 & 1.113 & 0.375 & 9.455 & 1,290 \\
\hline $\mathrm{ROA}$ & 5.355 & 15.085 & 7.280 & -96.510 & 119.740 & 1,183 \\
\hline ROS & 15.455 & 105.363 & 0.703 & -98.932 & 2328.570 & 1,164 \\
\hline
\end{tabular}

Notes:

This table shows descriptive statistics for the board design mechanisms, the control variables, and the performance measures. The board design mechanisms are classified according to their primary function (interest alignment, information provision, and decisiveness) as discussed in Section 2. Table 1 defines the variables, and the sample is all non-financial firms listed on the Oslo Stock Exchange at least once by yearend over the period 1989-2002.

show that powerful owners are mostly absent as inside monitors. ${ }^{13}$ The board's independence of the CEO as measured by (2) is medium in the sense that the CEO and the average director have roughly the same tenure. Still, there is large variation in board tenure across the sample, which is necessary for a valid test of the independence hypothesis.

13 Norwegian firms have a less concentrated ownership structure than in any other European country except the UK. For example, the average largest owner holds close to $50 \%$ of voting equity in a continentalEuropean public firm, $29 \%$ in Norway, and $15 \%$ in the UK. The corresponding US figure is $3 \%$ (Barca and Becht, 2001). Norway has a civil law regime, which is generally considered less investor-protective than common law. Nevertheless, La Porta et al. (2000) find that Norway's regulatory environment provides better protection of shareholder rights than the average common law country. According to their theory of institutionally determined ownership structures, the strong investor protection is a major reason why Norway's ownership concentration is so low. 
The network measure shows that boards differ considerably in their information access through their directors' links to other boards. The figures for decisiveness show that the average board has 6.5 directors, which is a very small board by international standards. ${ }^{14}$ Female directors are rare, and there is large age heterogeneity within the board. The median firm has one employee director, and the average fraction across all firms is $15.3 \%$. Because employee directors may behave differently than other directors, we measure board size as well as gender mix both with and without employee directors (SizeAll vs. Size and GenderAll vs. Gender, respectively).

Table 3 shows bivariate correlation coefficients between the main explanatory variables from model (1). Kennedy (2008) argues that coefficients above 0.70 may reflect multicollinearity problems in regressions. Every correlation in the table is far below that level. Also, Hsiao (2003, pp. 3-4) argues that multicollinearity is more unlikely in panel data settings, since this normally involves more data points and larger data variability than a cross-section. Moreover, our regressions use definitions of board size and gender that exclude employee directors. The latter is important, as the correlation between board size and the fraction of employee directors is 0.65 when employee directors are included in the size measure (SizeAll), but only 0.07 when it ignores employee directors (Size). This suggests multicollinearity is not a problem in our regressions unless employee directors are included in the size and gender proxies. Section 5 addresses that question.

\section{THE BASE-CASE ESTIMATES}

The general structure of our panel data relation (Wooldridge, 2002, p. 251) is:

$$
V_{i t}=\theta+\boldsymbol{\alpha}(\text { Board mechanisms })_{i t}+\beta V_{i, t-1}+\gamma(\text { Controls })_{i t}+c_{i}+v_{i t}\left\{\begin{array}{l}
i=1,2, \ldots, N \\
t=1,2, \ldots, T
\end{array}\right.
$$

where $i$ is the firm, $t$ is the time period, $\theta$ is a constant, $\alpha$ and $\gamma$ are the coefficient vectors for board mechanisms and controls, respectively, $\beta$ is the coefficient of lagged firm value, and $c_{i}$ is the unobserved, time-independent fixed effect of firm $i$.

We observe $V_{i t}$ in (3) and the explanatory variables representing board mechanisms, lagged performance, and controls, and we want to estimate $\alpha, \beta$, and $\gamma$. If we ignore the time-series nature of the data and simply use a pooled approach, dependence in the residuals will create problems. This dependence may be due to a firm fixed effect, i.e., a constant impact on a given firm's performance in every year. It may also be due to factors which influence the performance of all firms at a given point in time, such as an overall economic shock. Such effects may also introduce endogenity caused by omitted variables which influence both performance and the determinants used in the regression.

14 Wymeersch (1998, pp. 1105-9) reports an average board size of 12 directors in France and Italy, 10 in Belgium and the UK, and 7 in the Netherlands. The average size of the German supervisory board is 13 (Hopt, 1998, p. 248). Carter and Lorsch (2004) find that the average US board has 12 directors, which is down from 16 in the 1980s. Although the largest boards in our sample become less common over time, the average size is very stable. For instance, the $25 \%$ largest boards have on average 8.97 members in the first half of the sample period and 8.67 in the second. 


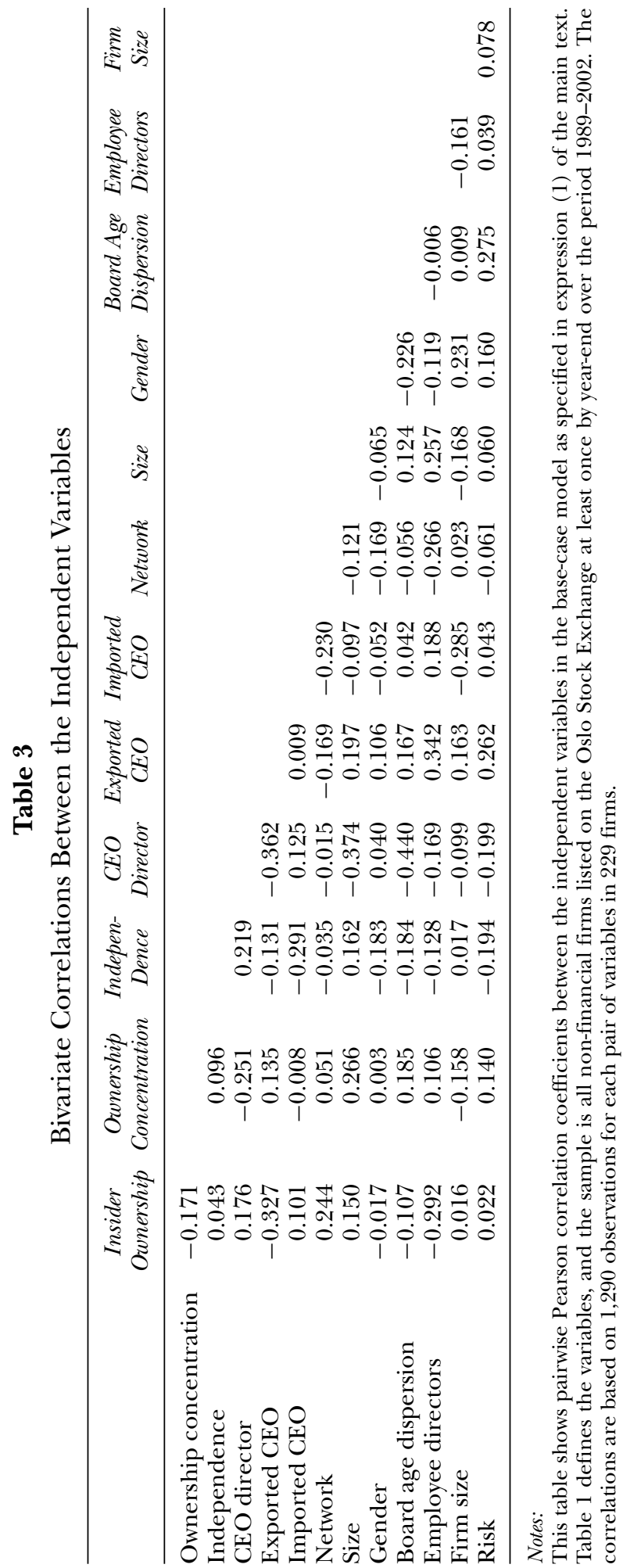


It is well known that the stronger these effects, the more the estimates from a pooled regression will be biased and inefficient (Hsiao, 2003). Therefore, the estimates should be adjusted for unobservable firm and year effects (Petersen, 2009; and Gow et al., 2010). Fixed effects estimation with firm-robust (clustered) standard errors will accomplish this (Wooldridge, 2002). Fixed effects estimation accounts for unobservable determinants of a firm's performance that stay constant over time. Firmrobust standard errors removes heterogeneity in the residuals caused by common shocks in a specific year. ${ }^{15}$

Since the unobserved $c_{i}$ in (3) is constant over time per firm, this fixed firm effect disappears when we add a dummy variable per firm. Therefore, our base-case estimates account for endogenity driven by (i) omitted time-invariant firm characteristics, (ii) by the fact that the board is designed before the firm's performance is measured, and (iii) by the lagged performance measure. We consider additional controls for endogenity in Section 5, which also estimates the seriousness of ignoring the panel structure.

Table 4 shows the results. The first column reports the coefficient estimates based on the unstandardized variables. The second column shows the estimates based on standardized variables, which express economic significance in a more transparent way. Because the standardized variable has an expected value of zero and a standard deviation of one, its regression coefficient shows the number of standard deviations performance is expected to change if the board mechanism changes by one standard deviation. Thus, the higher the absolute value of the standardized coefficient, the stronger the economic significance of the board mechanism. Since the $p$-value in the third column is always identical for both coefficient types, we only report standardized coefficients in the following. The Wald statistic rejects the hypothesis that the estimated coefficient vector equals zero (Greene, 2003, p. 107). We limit the attention to individual coefficients with at least one star; i.e., a $p$-value of $10 \%$ or less.

For the alignment mechanisms, the two ownership variables are not significantly related to firm value. This is in line with several board studies, which often find that when more governance mechanisms than just ownership are included in the model, such as in (1), the relationship between ownership and performance becomes weaker (Cotter et al., 1997). ${ }^{16}$ The finding is also consistent with the argument of Demsetz and Lehn (1985) and subsequent findings by e.g., Agrawal and Knoeber (1996) that optimally installed governance mechanisms that are unregulated have insignificant regression coefficients.

The insignificant relationship between board independence and performance is consistent with the hypothesis that although more independence increases monitoring incentives, it also reduces the CEO's willingness to share information (Adams and Ferreira, 2007). The net effect in our sample is zero, suggesting that most boards have optimal independence because they strike the proper balance between being a hands-off monitor and a hands-on management resource. The finding is also in line with most existing studies, which analyze a different institutional regime and use a different independence measure (Bhagat and Black, 2002). Thus, we cannot find

15 The adjustments for year effects can also be achieved by using time dummies. Petersen (2009) shows by simulation that the more firms relative to years in the panel, the more critical is adjustment for firm effects compared to time effects. Since our sample has 229 firms and 14 years, accounting for fixed firm effects is the more important adjustment.

16 Hermalin and Weisbach (1991), Byrd and Hickman (1992), Yermack (1996), Cotter et al. (1997) and Bhagat and Black (2002) all find a positive relationship between insider holdings and firm value, but the relationship is only significant in Hermalin and Weisbach (1991) and Yermack (1996). 


\section{Table 4}

The Relationship Between Firm Value, Board Design Mechanisms, and Controls in the Base-Case Model

\begin{tabular}{lccc}
\hline & Unstandardized & Standardized & p-value \\
\hline Alignment & & & \\
Insider ownership & 0.267 & 0.046 & 0.467 \\
Ownership concentration & 0.098 & 0.021 & 0.535 \\
Independence & 0.004 & -0.008 & 0.623 \\
Information & & & \\
CEO director & 0.066 & 0.026 & 0.370 \\
Exported CEO & -0.013 & -0.010 & 0.704 \\
Imported CEO & -0.150 & -0.013 & 0.504 \\
Network & $1.159^{* * *}$ & $0.080^{* * *}$ & 0.000 \\
Decisiveness & & & \\
Size & $-0.068^{* * *}$ & $-0.079^{* * *}$ & 0.003 \\
Gender & $-0.578^{* *}$ & $-0.049^{* *}$ & 0.013 \\
Board age dispersion & 0.002 & 0.008 & 0.770 \\
Employee directors & $-1.018^{* * *}$ & $-0.142^{* * *}$ & 0.000 \\
Lagged firm value & & & \\
Q & & $0.088^{*}$ & 0.092 \\
Controls & $0.087^{*}$ & & \\
Firm size & & -0.049 & 0.393 \\
Risk & -0.023 & 0.002 & 0.818 \\
$R^{2}$ & 0.008 & 0.041 & \\
Wald test & 0.041 & 0.000 & \\
Observations & 0.000 & 1,290 & \\
Firms & 1,290 & 229 & \\
\hline
\end{tabular}

Notes:

This table shows the base-case estimates of the model in expression (1) of the main text. We use OLS, firm dummies, and firm-robust (clustered) standard errors. The dependent variable is Tobin's $Q$, which we measure as the market value of the firm over its book value. The first column of results reports unstandardized (regular) coefficient estimates. The second column shows the estimates based on the standardized variables, which we construct by deducting each observation from its sample overall mean value and dividing by its standard deviation. The $p$-value in the third column is identical for the unstandardized and the standardized coefficient. Statistically significant coefficients at the $1 \%, 5 \%$ and $10 \%$ level are marked with $* * *, * *$ and $*$, respectively. Table 1 defines the variables, and the sample is all non-financial firms listed on the Oslo Stock Exchange at least once by year-end over the period 1989-2002.

support for the political argument that the ability to create value will improve if board independence is made mandatory by law or recommended by code.

Our information centrality measure reflects direct and indirect network effects that occur when the firm's directors meet directors on other boards. The estimates show a positive association between network and firm value. This result is consistent with the finding by Ferris et al. (2003) that well-connected directors add extra value. It does not support the Fich and Shivdasani (2006) result that busy directors are underperforming. One potential reason why the international evidence is mixed is that the number of seats held is a noisy measure of network value. We explore this possibility in Section 5. Notice also that whether or not the CEO has a vote in the board is not significant in the table. This is consistent with the notion that CEO power in the board room is more a function of presence than voting rights. 
Every coefficient estimate under board decisiveness is negative and significant except for age dispersion. Although the inverse relationship between board size and performance is in line with the existing literature, it is remarkable that this pattern turns up in our sample as well, which has firms with very small boards by international standards. This result suggests that optimal board size is indeed very moderate. If board size captures diversity in a way which is not reflected in the other decisiveness mechanisms, the finding supports the idea that diversity reduces board decisiveness.

The inverse relationship between gender mix and performance is in line with earlier studies that use different models in different institutional settings. Thus, this seems a quite robust result. Finally, the use of employee directors is negatively associated with performance. Although the sample firms operate under a different co-determination regime, our finding is consistent with most of the evidence from Germany. This suggests that in both environments, employee directors successfully defend their interests in the board room at the expense of stockholders. Stated differently, mandating employee directors causes an over-optimal use of this director type from the stockholders' point of view. ${ }^{17}$

In terms of economic significance, the standardized coefficients show that among the estimates with a $p$-value of $10 \%$ or less, employee directors is the most powerful variable, followed by network, size, and gender. To illustrate, Table 2 shows that the average firm has a Tobin's $Q$ of 1.428 and an employee director fraction of $15.3 \%$, the standard deviations being 1.019 and $16.0 \%$, respectively. Along with the standardized coefficients from Table 4, this implies that if employee directors increases by one standard deviation from its mean value of $15.3 \%$ to a level of $31.3 \%$, expected Tobin's $Q$ decreases from 1.428 to 1.283 , i.e., by $10.2 \%$. Increasing gender diversity by one standard deviation from the sample mean decreases expected $Q$ from 1.428 to 1.378 , i.e., by $3.5 \%$.

Summarizing, the test of the base-case estimates of the model in expression (1) shows that more directors with multiple seats relates positively to firm value. This is consistent with the hypothesis that the network of well-connected directors creates value in the board room. In contrast, larger board size, more gender mix, and more employee directors is negatively associated with performance. This suggests heterogenous boards are less effective decision makers. All these relationships are statistically significant, and the economic significance is strongest for the decisiveness mechanisms. Finally, independence and firm value are not systematically related.

These findings provide no economic argument for regulating more independence, more diversity or less busy directors. That is, we find no support for requiring by law or recommending by code that a minimum fraction of directors be independent, employees, or of a particular gender. Neither do these findings suggest that multiple directorships should be discouraged. The fact that employee directors and gender diversity relate negatively and significantly to firm value may reflect that, unlike the insignificant independence or insider ownership variables, these board mechanisms are not at their optimal level (Demsetz and Lehn, 1985). This means that if anything, the regulatory implication is the opposite of what has been argued in the public:

17 The lagged value of the dependent variable enters the regression with a positive and significant coefficient. This suggets a feedback from past performance to current performance and current board composition. We investigate the seriousness of this endogeneity in Section 5 . Lagged terms may also produce a downward bias in the estimated coefficients which is larger the closer $\beta$ is to 1 (Nickell, 1981). Since our estimated $\beta$ is close to zero, downward bias is not a serious problem in this case. 
Politicians should mandate less employee directors, less gender diversity, and more networked directors. The independence mechanism needs no regulatory attention.

We should emphasize that these implications for public policy only concern the sign and not the magnitude of how new regulation may influence performance. This is particularly true for gender diversity, where the fraction of women on the board was forced from $3.2 \%$ for the average firm in the unregulated sample period to $40-60 \%$ for all firms afterwards. Thus, we are not implying that the absolute value of our coefficient estimate applies to a sample with a more than ten-fold increase in average gender diversity. Our point is that the estimated relationship between gender and performance in the unregulated period provides no economic argument for the subsequent regulation.

\section{ROBUSTNESS}

We start by analyzing the effect of using alternative econometric techniques, followed by alternative model structures. Finally, we consider the robustness to different ways of operationalizing key theoretical concepts.

\section{(i) Econometric Approach}

In order to check if panel data techniques are required, we first use an OLS approach with pooled data. This means the fixed effect $c_{i}$ term in (3) is absorbed by the overall constant term $\theta$. The residuals from these pooled regressions allow for an ANOVA test of the null hypothesis that the data may be pooled without problems because the observations are independently distributed (Hsiao, 2003).

Column (A) of Table 5 repeats the base-case estimates from Table 4 as a reference. Columns (B) and (C) show the estimates from pooled OLS without and with time and industry proxies, respectively. Even though the $R^{2}$ is much higher in (B) and (C), several key estimates deviate considerably from those in (A). For instance, insider ownership is now significant, board size is not, and employee directors is insignificant in (C). Not surprisingly, the ANOVA tests show that these pooled OLS regressions are seriously biased. The hypothesis of common means is rejected, and a test for the null hypothesis of equal variances across firms (not reported) produces the same result. The White test of heteroskedasticity and the Hausman tests of equal coefficient vectors strengthen the impression of misspecifications in (B) and (C). Also, adding industry and time dummies to $(\mathrm{B})$ in order to get $(\mathrm{C})$ does not help. Hence, the heterogeneity is at the firm level rather than the industry or time levels. By implication, careful modeling of the firm-specific panel structure is essential in our setting.

The fixed effect in model (1) does not capture time invariant variables like the firm's industry. This problem is not shared by the random effects approach, which is estimated with industry dummies in column (D). In this model the firm's time invariant characteristics are absorbed by the error term. We use GLS to adjust for the resulting heterogeneity in randomness across groups (Wooldridge, 2002). The table shows that the coefficient estimates are quite consistent in (A) and (D). Thus, it is not essential whether we account for unobservable characteristics by the random effects or the fixed effects approach.

Endogeneity may not just be addressed by a panel approach, but also by using instruments that correlate weakly with performance and strongly with the endogenous 
Table 5

Alternative Econometric Techniques

\begin{tabular}{|c|c|c|c|c|c|}
\hline & \multirow{2}{*}{$\begin{array}{c}\text { Base-Case } \\
\text { (A) }\end{array}$} & \multicolumn{2}{|c|}{ Pooled OLS } & \multirow{2}{*}{$\begin{array}{l}G L S \\
(D)\end{array}$} & \multirow{2}{*}{$\begin{array}{c}2 S L S \\
(E)\end{array}$} \\
\hline & & (B) & $(C)$ & & \\
\hline \multicolumn{6}{|l|}{ Alignment } \\
\hline Insider ownership & 0.046 & $0.038^{* *}$ & $0.051^{* *}$ & 0.050 & -0.001 \\
\hline Ownership concentration & 0.021 & -0.034 & -0.019 & 0.002 & 0.010 \\
\hline Independence & -0.008 & 0.007 & 0.012 & 0.001 & -0.001 \\
\hline \multicolumn{6}{|l|}{ Information } \\
\hline CEO director & 0.026 & -0.022 & -0.008 & 0.013 & 0.011 \\
\hline Exported CEO & -0.010 & -0.003 & -0.004 & -0.003 & 0.001 \\
\hline Imported CEO & -0.013 & -0.021 & -0.018 & -0.013 & -0.017 \\
\hline Network & $0.080^{* * *}$ & $0.083^{* * *}$ & $0.083^{* * *}$ & $0.082^{* * *}$ & $0.067 * * *$ \\
\hline \multicolumn{6}{|l|}{ Decisiveness } \\
\hline Size & $-0.079 * * *$ & -0.019 & -0.025 & $-0.054^{* *}$ & $-0.093^{* * *}$ \\
\hline Gender & $-0.049^{* *}$ & -0.013 & $-0.041^{*}$ & $-0.042^{* *}$ & $-0.038^{* *}$ \\
\hline Board age dispersion & 0.008 & -0.002 & 0.001 & 0.003 & -0.002 \\
\hline Employee directors & $-0.142^{* * *}$ & $0.038^{* *}$ & 0.012 & $-0.081^{* * *}$ & $-0.096^{* * *}$ \\
\hline \multicolumn{6}{|l|}{ Lagged firm value } \\
\hline $\mathrm{Q}_{t-1}$ & $0.088^{*}$ & $0.608^{* * *}$ & $0.529 * * *$ & $0.153^{* * *}$ & $0.106^{* *}$ \\
\hline \multicolumn{6}{|l|}{ Controls } \\
\hline Firm size & -0.049 & $-0.057 * * *$ & $-0.059 * * *$ & -0.055 & -0.054 \\
\hline Risk & 0.002 & -0.026 & -0.018 & -0.005 & -0.007 \\
\hline Constant & & $-0.094^{* * *}$ & $-0.218^{* * *}$ & $-0.569 * * *$ & \\
\hline Time dummies & No & No & Yes & No & No \\
\hline Industry dummies & No & No & Yes & Yes & No \\
\hline Fixed effects & Yes & No & No & No & Yes \\
\hline Random effects & No & No & No & Yes & No \\
\hline$R^{2}$ & 0.041 & 0.519 & 0.558 & 0.110 & \\
\hline Wald test & 0.000 & & & & \\
\hline ANOVA test: Individual & & 0.000 & 0.000 & & \\
\hline ANOVA test: Time & & 0.000 & 0.000 & & \\
\hline ANOVA test: Joint & & 0.000 & 0.000 & & \\
\hline Hausman test & & 0.000 & 0.000 & 0.000 & \\
\hline White Test & & 0.000 & 0.000 & & \\
\hline Sargan's $J$ test & & & & & 0.037 \\
\hline Instrument endogeneity & & & & & 0.024 \\
\hline Observations & 1,290 & 1,290 & 1,290 & 1,290 & 1,290 \\
\hline Firms & 229 & 229 & 229 & 229 & 229 \\
\hline
\end{tabular}

Notes:

This table shows how the base-case estimates from Table 4 (copied in column (A)) depend on alternative estimation methods. OLS is Ordinary Least Squares, GLS is Generalized Least Squares, and 2SLS is 2Stage Least Squares. The dependent variable is Tobin's $Q$, which we measure as the market value of the firm over its book value. The coefficient estimates are based on standardized variables, which we construct by deducting each observation from its sample overall mean value and dividing by its standard deviation. Statistically significant coefficients at the $1 \%, 5 \%$ and $10 \%$ level are marked with $* * *, * *$ and $*$, respectively. Table 1 defines the variables, and the sample is all non-financial firms listed on the Oslo Stock Exchange at least once by year-end over the period 1989-2002.

independent variables. We use the two-stage least squares (2SLS) method for this purpose, estimating a single-equation model with instruments. This is less complicated than trying to capture endogeneity in the economic sense, which requires a system of simultaneous equations. The governance theory for such a comprehensive model 
does not seem to exist yet (Larcker and Rusticus, 2007). Thus, our approach addresses endogeneity in a statistical sense, which concerns the dependence of the instruments upon the error term (Wooldridge, 2002). We need at least as many instruments as endogenous independent variables to identify their coefficients. In addition to performance, the endogenous variables we specify are board independence, CEO director, exported CEO, imported CEO, board size, gender, and board age dispersion. The exogenous variables in the estimation are the two ownership variables, network, employee directors, risk, and firm size.

Panel data estimation offers rich opportunities for constructing instruments (Cameron and Trivedi, 2005). The instruments we choose are the raw, the timedemeaned, and the firm-specific mean of the exogenous variables and the constant. Moreover, we use the levels and the firm-specific means of each firm's endogeneous variables. Thus, the model is overidentified with 14 instruments. We specify the model with fixed effects and estimate it with 2SLS.

The results are reported in column (E). The test statistics show that the instruments are valid, and that the regression carries no endogeneity bias. Moreover, the findings are consistent with the base-case estimates in column (A). Thus, both (D) and (E) suggest that the control for endogeneity inherent in the base-case OLS approach with fixed effects and firm-robust standard errors is sufficient. ${ }^{18}$ In unreported results, we find that the statistical significance and also the relative economic significance of the board mechanisms remain unchanged if we use their lagged values as instruments. Thus, endogeneity in terms of reverse causation is unimportant in our setting. This is possibly due to the other controls for endogeneity analyzed above and the institutional feature that the board is chosen before performance is measured.

\section{(ii) Model Structure}

We first analyze alternative ways of accounting for firm size, subsequently considering different approaches to modeling the ownership structure.

Firm size may matter for the role of employee directors in value creation. Except for certain industries, firms in our sample with more than 200 employees are required by law to appoint employee directors, whereas firms with 31-200 employees must only do so if at least half the employees vote for it. Thus, the employee director effect found so far may be a large firm effect which is not fully captured by the firm size variable. Size may also interact with gender diversity, since the bivariate correlations in Table 3 suggest that larger firms have a higher fraction of female directors. We analyze this issue in Table 6, where we exclude firm size from the model in column (A). Columns (B) and (C) both include firm size, but they estimate the model separately in subsamples of firms with more than and up to 200 employees, respectively.

The estimates in column (A) are practically identical to those in Table 4. Thus, controlling linearly for size in the full sample does nothing to the performance effect of employee directors and gender mix. This also holds for employee directors in

18 The model in expression (1) has the lagged value of the dependent variable as one of its independent variables. This allows for endogeneity through feedback from past performance to current performance and current board design (Wooldridge, 2002). Thus, any difference between this model and an otherwise identical model which ignores this feature would reflect the effect of disregarding the possibility that board mechanisms are partially driven by performance. 
Table 6

Controlling for Firm Size

\begin{tabular}{|c|c|c|c|}
\hline & $\begin{array}{c}(A) \\
\text { No Firm } \\
\text { Size Control }\end{array}$ & $\begin{array}{l}(B) \\
\text { Large } \\
\text { Firms }\end{array}$ & $\begin{array}{l}(C) \\
\text { Small } \\
\text { Firms }\end{array}$ \\
\hline \multicolumn{4}{|l|}{ Alignment } \\
\hline Insider ownership & 0.045 & -0.019 & 0.114 \\
\hline Ownership concentration & 0.013 & $0.071^{*}$ & -0.054 \\
\hline Independence & -0.006 & 0.001 & -0.023 \\
\hline \multicolumn{4}{|l|}{ Information } \\
\hline CEO director & 0.027 & 0.018 & 0.022 \\
\hline Exported CEO & -0.010 & -0.005 & -0.013 \\
\hline Imported CEO & -0.011 & -0.003 & -0.015 \\
\hline Network & $0.076^{* * *}$ & $0.081^{* * *}$ & 0.082 \\
\hline \multicolumn{4}{|l|}{ Decisiveness } \\
\hline Size & $-0.085^{* * *}$ & $-0.072^{* *}$ & $-0.098^{*}$ \\
\hline Gender & $-0.046^{* *}$ & $-0.048^{* *}$ & -0.003 \\
\hline Board age dispersion & 0.009 & 0.027 & -0.012 \\
\hline Employee directors & $-0.147^{* * *}$ & $-0.127^{* * *}$ & $-0.192^{* *}$ \\
\hline \multicolumn{4}{|l|}{ Lagged firm value } \\
\hline$Q_{t-1}^{\infty}$ & $0.085^{*}$ & $0.166^{* *}$ & 0.020 \\
\hline \multicolumn{4}{|l|}{ Controls } \\
\hline Firm size & & 0.023 & -0.066 \\
\hline Risk & 0.016 & -0.003 & 0.003 \\
\hline$R^{2}$ & 0.039 & 0.066 & 0.050 \\
\hline Observations & 1,335 & 859 & 340 \\
\hline Firms & 236 & 164 & 87 \\
\hline
\end{tabular}

Notes:

This table explores whether the base-case estimates in Table 4 depend on how we control for firm size. The model in column (A) makes no control for size, whereas columns (B) and (C) estimate the base-case model on the two subsamples of large firms and small firms, respectively. A large firm has at least 201 employees, and a small firm has less. Every model has the Tobin's Q ratio as the dependent variable and is estimated with fixed effects OLS and firm-robust standard errors. The coefficient estimates are based on standardized variables, which we construct by deducting each observation from its sample overall mean value and dividing by its standard deviation. Statistically significant coefficients at the $1 \%, 5 \%$ and $(10 \%)$ level are marked with $* * *, * *$ and $\left.t^{*}\right)$, respectively. Table 1 defines the variables, and the sample is all non-financial firms listed on the Oslo Stock Exchange at least once by year-end over the period 1989-2002.

the two sub-samples. However, the gender effect is strongest in large firms. Notice, however, that these firms constitute over $70 \%$ of the overall sample.

A common way of accounting for insider entrenchment is by adding a quadratic insider term in the regression (McConnell and Servaes, 1990; and Lasfer, 2006). Column (A) in Table 7 expands the model in expression (1) by such a term. Neither the linear nor the quadratic term has a significant coefficient, and all remaining estimates are virtually identical to those in Table 4 . Thus, whether or not we account explicitly for entrenchment has no impact on our findings.

The ownership variables used so far are based on cash flow rights. In dual-class firms, however, the investor's cash flow rights may differ from the voting rights, which is what matters for controlling the firm's behavior (Ben-Amar and André, 2006; and Bozec and Laurin, 2007). To account for potential separation between ownership and control, the ownership structure variables in column (B) of the table only reflect the 
Table 7

Accounting for the Ownership Structure

\begin{tabular}{|c|c|c|c|}
\hline & $\begin{array}{c}(A) \\
\text { Entrenchment }\end{array}$ & $\begin{array}{c}(B) \\
\text { Voting Shares }\end{array}$ & $\begin{array}{c}(C) \\
\text { Dual Shares }\end{array}$ \\
\hline \multicolumn{4}{|l|}{ Alignment } \\
\hline Insider ownership & -0.063 & 0.043 & 0.050 \\
\hline Insider ownership sqrd & 0.113 & & \\
\hline Ownership concentration & 0.021 & 0.029 & $0.033^{*}$ \\
\hline Independence & -0.008 & -0.008 & 0.001 \\
\hline \multicolumn{4}{|l|}{ Information } \\
\hline CEO director & 0.027 & 0.027 & 0.016 \\
\hline Exported CEO & -0.011 & -0.012 & -0.004 \\
\hline Imported CEO & -0.012 & -0.013 & -0.014 \\
\hline Network & $0.080^{* * *}$ & $0.083^{* * *}$ & $0.087^{* * *}$ \\
\hline \multicolumn{4}{|l|}{ Decisiveness } \\
\hline Size & $-0.078 * * *$ & $-0.079 * * *$ & $-0.054^{* *}$ \\
\hline Gender & $-0.049 * * *$ & $-0.046^{* *}$ & $-0.042^{* *}$ \\
\hline Board age dispersion & 0.008 & 0.009 & 0.004 \\
\hline Employee directors & $-0.141^{* * *}$ & $-0.150^{* * *}$ & $-0.086^{* * *}$ \\
\hline \multicolumn{4}{|l|}{ Lagged firm value } \\
\hline $\mathrm{Q}_{t-1}$ & $0.088^{*}$ & $0.089^{*}$ & $0.152^{* * *}$ \\
\hline \multicolumn{4}{|l|}{ Controls } \\
\hline Firm size & -0.049 & -0.050 & -0.055 \\
\hline Risk & 0.003 & 0.005 & -0.002 \\
\hline Constant & & & $-0.568^{* * *}$ \\
\hline Panel method & Fixed & Fixed & Random \\
\hline Industry dummies & No & No & Yes \\
\hline$R^{2}$ & 0.042 & 0.044 & 0.112 \\
\hline Observations & 1,290 & 1,250 & 1,241 \\
\hline Firms & 225 & 210 & 208 \\
\hline
\end{tabular}

Notes:

This table shows the effect of including alternative characteristics of the ownership structure. Column (A) adds a quadratic insider term to the model in expression (1) in the main text to account for potential entrenchment, column (B) measures ownership concentration by voting shares, only, and column (C) measures ownership concentration by a dummy variable to the base-case model which is one for firms with dual-shares and zero otherwise. The table shows the estimates based on the standardized variables, which we construct by deducting each observation from its sample overall mean value and dividing by its standard deviation. Every model has the Tobin's $Q$ ratio as the dependent variable and is estimated with OLS, firm dummies, and firm-robust standard errors. Statistically significant coefficients at the $1 \%, 5 \%$ and $(10 \%)$ level are marked with $* * *, * *$ and $(*)$, respectively. Table 1 defines the variables, and the sample is all non-financial firms listed on the Oslo Stock Exchange at least once by year-end over the period 1989-2002.

voting rights. Column (C) uses cash flow rights, but adds a dummy variable which is one for firms with a dual share structure and zero otherwise. As shown by the table, the key estimates are close to those of the base-case estimates with fixed effects (Table 4) and random effects (column (D) of Table 5), respectively.

\section{(iii) Empirical Proxies}

This section considers whether the base-case results in Table 4 depend on how we measure performance, independence, director network, and board size. 
Table 8

Robustness to the Performance Measure

\begin{tabular}{lccc}
\hline & $Q$ & $R O A$ & $R O S$ \\
\hline Alignment & & & \\
Insider ownership & 0.046 & -0.031 & -0.017 \\
Ownership concentration & 0.021 & 0.031 & 0.030 \\
Independence & -0.008 & -0.004 & -0.005 \\
Information & & & \\
CEO director & 0.026 & 0.018 & 0.019 \\
Exported CEO & -0.01 & 0.022 & -0.011 \\
Imported CEO & -0.013 & 0.023 & 0.020 \\
Network & $0.080^{* * *}$ & 0.022 & \\
Decisiveness & & & $-0.106^{* * *}$ \\
Size & $-0.079^{* * *}$ & $-0.078^{* *}$ & $-0.084^{* * *}$ \\
Gender & $-0.049^{* *}$ & $-0.085^{* * *}$ & -0.047 \\
Board age dispersion & 0.008 & 0.006 & $-0.186^{* * *}$ \\
Employee directors & $-0.142^{* * *}$ & $-0.162^{* * *}$ & \\
Lagged firm value & & & $-0.222^{* * *}$ \\
Performance at $t-1$ & $0.088^{*}$ & -0.010 & \\
Controls & & & -0.070 \\
Firm size & -0.049 & 0.046 & -0.107 \\
Risk & 0.002 & -0.034 & 0.089 \\
$R^{2}$ & 0.041 & 0.017 & 1,163 \\
Observations & 1,290 & 1,283 & 206 \\
Firms & 229 & 225 & \\
\hline
\end{tabular}

Notes:

This table shows the sensitivity of the base-case estimates from Table 4 to alternative ways of measuring performance. $\mathrm{Q}$ is the Tobin's $\mathrm{Q}$ ratio, ROA is book return on assets, and ROS is accounting return on stock. Every model is estimated with OLS, firm fixed effects, and firm-robust standard errors. The coefficient estimates are based on standardized variables, which we construct by deducting each observation from its sample overall mean value and dividing by its standard deviation. Statistically significant coefficients at the $1 \%, 5 \%$ and $10 \%$ level are marked with $* * *, * *$ and $*$, respectively. Table 1 defines the variables, and the sample is all non-financial firms listed on the Oslo Stock Exchange at least once by year-end over the period 1989-2002.

The performance measure used so far reflects the market value of the firm per unit of book value. Although this is the most common empirical proxy in the governance literature, alternative measures have been used, particularly book (accounting) return on assets (ROA) and market return on stock (ROS) (Brown and Caylor, 2006 and 2009; and Bhagat and Bolton, 2008). As shown by Table 8, however, the results are quite robust to how we measure performance. Except for the effect of networks when performance is measured as book returns, the relationship between board characteristics and performance is insensitive to the way performance is measured.

The independence measure used so far is based on the Hermalin and Weisbach (1998) logic that what matters is the tenure of non-CEO directors vs. the tenure of the CEO. Carter and Lorsch (2004) argue that board independence concerns absolute tenure rather than relative, and that independence decreases rather than increases as tenure grows. We test this competing hypothesis by alternatively operationalizing independence as board tenure, CEO tenure, and chair tenure. Under the 
Table 9

Alternative Proxies for Board Independence, Director Network, Board Size, and Gender Diversity

\begin{tabular}{|c|c|c|c|c|c|c|}
\hline & $\begin{array}{l}(A) \\
\text { Board } \\
\text { Tenure }\end{array}$ & $\begin{array}{c}(B) \\
\text { CEO } \\
\text { Tenure }\end{array}$ & $\begin{array}{l}\text { (C) } \\
\text { Chair } \\
\text { Tenure }\end{array}$ & $\begin{array}{l}(D) \\
O D\end{array}$ & $\begin{array}{l}(E) \\
B T \\
O D\end{array}$ & $\begin{array}{c}(F) \\
\text { Size and } \\
\text { Gender }\end{array}$ \\
\hline Alignment & & & & & & \\
\hline Insider ownership & 0.045 & 0.045 & 0.047 & 0.050 & 0.049 & 0.048 \\
\hline $\begin{array}{l}\text { Ownership } \\
\text { concentration }\end{array}$ & 0.019 & 0.020 & 0.020 & 0.017 & 0.015 & 0.017 \\
\hline Independence & -0.020 & -0.019 & -0.017 & -0.010 & -0.030 & -0.011 \\
\hline $\begin{array}{l}\text { Information } \\
\text { CEO director } \\
\text { Exported CEO } \\
\text { Imported CEO } \\
\text { Network }\end{array}$ & $\begin{array}{c}0.027 \\
-0.009 \\
-0.015 \\
0.079 * * *\end{array}$ & $\begin{array}{c}0.028 \\
-0.007 \\
-0.014 \\
0.080^{* * *}\end{array}$ & $\begin{array}{c}0.028 \\
-0.009 \\
-0.014 \\
0.079^{* * *}\end{array}$ & $\begin{array}{c}0.025 \\
-0.026 \\
-0.028 \\
0.085^{* *}\end{array}$ & $\begin{array}{c}0.026 \\
-0.025 \\
-0.031 \\
0.088^{* *}\end{array}$ & $\begin{array}{r}0.026 \\
-0.027 \\
-0.027 \\
0.089^{* *}\end{array}$ \\
\hline $\begin{array}{l}\text { Decisiveness } \\
\text { Size } \\
\text { Gender } \\
\text { Board age dispersion } \\
\text { Employee directors }\end{array}$ & $\begin{array}{c}-0.078^{* * *} \\
-0.049^{* * *} \\
0.005 \\
-0.139^{* * *}\end{array}$ & $\begin{array}{c}-0.076^{* * *} \\
-0.050^{* * *} \\
0.005 \\
-0.140^{* * *}\end{array}$ & $\begin{array}{c}-0.076^{* * *} \\
-0.049^{* * *} \\
0.008 \\
-0.139^{* * *}\end{array}$ & $\begin{array}{c}-0.062^{* *} \\
-0.054^{* * *} \\
0.010 \\
-0.128^{* * *}\end{array}$ & $\begin{array}{l}-0.060^{* *} \\
-0.054^{* * *} \\
0.007 \\
-0.123^{* * *}\end{array}$ & $\begin{array}{c}-0.077^{* *} \\
-0.009 \\
0.007 \\
-0.078^{*}\end{array}$ \\
\hline $\begin{array}{l}\text { Lagged firm value } \\
\mathbf{Q}_{t-1}\end{array}$ & $0.090^{*}$ & $0.090^{*}$ & $0.088^{*}$ & 0.082 & 0.083 & 0.083 \\
\hline $\begin{array}{l}\text { Controls } \\
\text { Firm size } \\
\text { Risk }\end{array}$ & $\begin{array}{r}-0.045 \\
0.001\end{array}$ & $\begin{array}{r}-0.047 \\
0.000\end{array}$ & $\begin{array}{r}-0.048 \\
0.001\end{array}$ & $\begin{array}{r}-0.048 \\
0.003\end{array}$ & $\begin{array}{r}-0.043 \\
0.000\end{array}$ & $\begin{array}{r}-0.046 \\
0.005\end{array}$ \\
\hline $\begin{array}{l}R^{2} \\
\text { Observations } \\
\text { Firms }\end{array}$ & $\begin{array}{c}0.043 \\
1,290 \\
229\end{array}$ & $\begin{array}{c}0.043 \\
1,290 \\
229\end{array}$ & $\begin{array}{c}0.043 \\
1,290 \\
229\end{array}$ & $\begin{array}{c}0.038 \\
1,289 \\
229\end{array}$ & $\begin{array}{c}0.039 \\
1,289 \\
229\end{array}$ & $\begin{array}{c}0.033 \\
1,290 \\
229\end{array}$ \\
\hline
\end{tabular}

Notes:

This table shows the results of using alternative operationalizations for board independence (columns (A)(C)), director network (column (D)), and a combination of the two (column (E)). In column (F) employee directors are included in the definition of board size and gender diversity. In every column, expression (1) of the main text defines the theoretical model. OD is the average number of outside directorships held by the firm's board members, and BT is the average tenure of the board members except the CEO. The dependent variable is Tobin's $Q$, which we measure as the market value of the firm over its book value. Every model is estimated with firm fixed effects OLS and firm-robust standard errors. The table shows the estimates based on the standardized variables, which we construct by deducting each observation from its sample overall mean value and dividing by its standard deviation. Statistically significant coefficients at the $1 \%, 5 \%$ and $10 \%$ level are marked with $* * *, * *$ and $*$, respectively. Table 1 defines the variables, and the sample is all non-financial firms listed on the Oslo Stock Exchange at least once by year-end over the period 1989-2002.

Carter-Lorsch hypothesis, the expected relationship to firm value is negative for board and chair tenure and zero for CEO tenure.

The second alternative operationalization is for the director network variable. Unlike our more elaborate proxy, existing papers simply use the average number of outside directorships. We expect the estimated coefficient of this coarser measure to have the same sign as our proxy, but to be less significant economically and statistically.

Table 9 re-estimates model (1) under alternative proxies for independence (columns (A)-(C)), director network (column (D)) and for one combination of the two (column (E)). Comparing the estimates to those in Table 4, the results are 
practically identical. This shows that the base-case findings are not driven by the choice of a more comprehensive alternative to the classic network measure (Fama, 1980). Neither are they due to an independence measure which uses relative rather than absolute tenure.

Finally, it may be argued that if we are concerned with the value effect of board size or gender diversity, it does not matter whether directors are elected by shareholders or by employees. Due to potential multicollinearity and the desire to distinguish between stockholder-driven and employee-driven explanations, however, we have so far excluded employee directors from the gender and board size variables. Column (F) re-estimates model (1), letting these two board characteristics reflect all the board's directors rather than only those elected by stockholders.

The relationships change for the decisiveness mechanisms, where gender becomes insignificant and employee directors becomes weaker statistically and economically. This is as expected, since the value effect of what used to be in the employee directors' variable only is now spread out over three variables (employee directors, size, and gender). This waters down the separate effects of gender and employee directors. Thus, including employee directors in the definition of size and gender prevents us from telling whether these two board characteristics per se interact with performance or whether we measure the effect of employee directors working indirectly through size and gender.

Overall, the robustness tests have shown that alternative ways of operationalizing performance, independence, information network, gender diversity, and board size have no fundamental effect on the relationship between firm value and board characteristics targeted by public policy. Moreover, the way we account for firm size and ownership structure is not critical. Finally, not controlling for endogeneity or for unobservable firm-specific effects will seriously bias the estimates. All these results strengthen our belief in the findings from the base-case estimates of model (1) as reported in Table 4 .

\section{CONCLUSIONS}

This paper has analyzed the politics of corporate governance in an empirical setting which allows us to study the economic rationale of both existing and future regulation of the board. We find that the current politics of board design cannot be justified by valuation arguments. In particular, our data provides no convincing economic reason for requiring by law or code that a minimum fraction of the firm's directors be employees, be independent, be of a certain gender, or only hold a few directorships. Rather, our evidence is consistent with the notion that owners design boards with the proper mix of hands-off monitors and hands-on advisers, that employees successfully protect their interests at the expense of capital providers, that heterogenous boards are less effective decision makers, and that multiple directorships create valuable networks. If anything, the regulatory implications of these findings are the opposite of the current regime. From the owners' point of view, politicians should ignore independence and encourage less gender diversity, fewer employee directors, and more directors with multiple seats. Alternatively, one could argue that for gender mix in particular, political arguments should not be based on beneficial economic consequences for the firm's stockholders. Rather, mandating gender diversity in the board room should be considered an inherent part of a broader political program to ensure 
equal opportunities. Implementing such a program seems costly for stockholders, but may still be beneficial for society at large.

\section{REFERENCES}

Adams, R. B. and D. Ferreira (2007), 'A Theory of Friendly Boards', Journal of Finance, Vol. 62, No. 1, pp. 217-50.

Performance', Journal of Financial Economics, Vol. 94, No. 2, pp. 291-309.

Agrawal, A. and C. R. Knoeber (1996), 'Firm Performance and Mechanisms to Control Agency Problems between Managers and Shareholders', Journal of Financial and Quantitative Analysis, Vol. 31, No. 3, pp. 377-97.

Barca, F. and M. Becht (2001), The Control of Corporate Europe (Oxford, UK: Oxford University Press).

Baysinger, B. D. and H. N. Butler (1985), 'Corporate Governance and the Board of Directors: Performance Effects of Changes in Board Composition', Journal of Law, Economics, and Organization, Vol. 1, No. 1, pp. 101-24.

Becht, M., P. Bolton and A. Röell (2003), 'Corporate Governance and Control', in G. Constantinides, M. Harris and R. Stulz (eds.), Handbook of the Economics of Finance, Volume 1A, Chapter 1 (Amsterdam: North-Holland), pp. 1-109.

Ben-Amar, W. and P. André (2006), 'Separation of Ownership from Control and Acquiring Firm Performance: The Case of Family Ownership in Canada', Journal of Business Finance E् Accounting, Vol. 33, No. 3-4, pp. 517-43.

Bhagat, S. and B. Black (1999), 'The Uncertain Relationship between Board Composition and Firm Performance', The Business Lawyer, Vol. 54, pp. 921-63.

_ (2002), 'The Non-correlation between Board Independence and Long Term Firm Performance', Journal of Corporation Law, Vol. 27, No. 2, pp. 231-74.

- and B. Bolton (2008), 'Corporate Governance and Firm Performance', Journal of Corporate Finance, Vol. 14, pp. 257-73.

Bozec, Y. and C. Laurin (2007), 'Large Shareholder Entrenchment and Performance: Empirical Evidence from Canada', Journal of Business Finance $\mathcal{E}$ Accounting, Vol. 35, No. 1, pp. 2549.

Brown, L. D. and M. L. Caylor (2006), 'Corporate Governance and Firm Valuation', Journal of Accounting and Public Policy, Vol. 25, pp. 409-34.

- (2009), 'Corporate Governance and Firm Operating Performance', Review of Quantitative Finance and Accounting, Vol. 32, No. 2, pp. 129-44.

Buchanan, J. M. and G. Tullock (1962), The Calculus of Consent. Logical Foundations of Constitutional Democracy (Ann Arbor, Michigan: The University of Michigan Press).

Byrd, J. W. and K. A. Hickman (1992), 'Do Outside Directors Monitor Managers?' Journal of Financial Economics, Vol. 32, pp. 195-221.

Cadbury, A. (2002), Corporate Governance and Chairmanship. A Personal View (Oxford: Oxford University Press).

Cameron, A. C. and P. K. Trivedi (2005), Microeconometrics. Methods and Applications (Cambridge, UK: Cambridge University Press).

Carter, C. B. and J. W. Lorsch (2004), Back to the Drawing Board (Boston, Mass.: Harvard Business School Press).

Carter, D. A., B. J. Simkins and W. G. Simpson (2003), 'Corporate Governance, Board Diversity and Firm Value', Financial Review, Vol. 38, pp. 33-53.

Coles, J. L., M. L. Lemmon and J. F. Meschke (2003), 'Structural Models and Endogeneity in Corporate Finance: The Link between Managerial Ownership and Corporate Performance', EFA 2003 Annual Conference Paper No. 693.

Conyon, M. J. and M. R. Muldoon (2006), 'The Small World of Corporate Boards', Journal of Business Finance E् Accounting, Vol. 33, No. 9 \& 10, pp. 1321-43.

Cotter, J. F., A. Shivdasani and M. Zenner (1997), 'Do Independent Directors Enhance Target Shareholder Wealth during Tender Offers?' Journal of Financial Economics, Vol. 43, pp. 195-218. 
Cronqvist, H., A. Low and M. Nilsson (2009), 'Persistence in Firm Policies, Firm Origin, and Corporate Culture: Evidence from Corporate Spin-offs', Robert Day School of Economics and Finance, Claremont Mckenna College, Research Paper No. 2009-2.

Demsetz, H. and K. Lehn (1985), 'The Structure of Corporate Ownership: Causes and Consequences', Journal of Political Economy, Vol. 93, No. 6, pp. 1155-77.

Eisenberg, T., S. Sundgren and M. T. Wells (1998), 'Larger Board Size and Decreasing Firm Value in Small Firms', Journal of Financial Economics, Vol. 48, pp. 35-54.

Falaye, O., V. Mehrotra and R. Morck (2006), 'When Labor has a Voice in Corporate Governance', Journal of Financial and Quantitative Analysis, Vol. 41, No. 3, pp. 489-510.

Fama, E. F. (1980), 'Agency Problems and the Theory of the Firm', Journal of Political Economy, Vol. 88, No. 2, pp. 288-307.

Fauver, L. and M. E. Fuerst (2006), 'Does Good Corporate Governance Include Employee Representation? Evidence from German Corporate Boards', Journal of Financial Economics, Vol. 82, No. 3, pp. 673-710.

Ferris, S. P., M. Jagannathan and A. Pritchard (2003), 'Too Busy to Mind the Business? Monitoring by Directors with Multiple Board Appointments', Journal of Finance, Vol. 58, No. 3, pp. 1087-111.

Fich, E. M. and A. Shivdasani (2006), 'Are Busy Boards Effective Monitors?' Journal of Finance, Vol. 61, No. 2, pp. 689-724.

FitzRoy, F. R. and K. Kraft (1993), 'Economic Effects of Codetermination', Scandinavian Journal of Economics, Vol. 95, No. 3, pp. 365-75.

Gilson, R. J. and R. Kraakman (1991), 'Reinventing the Outside Director: An Agenda for Institutional Investors', Stanford Law Review, Vol. 43, pp. 863-906.

Gjølberg, O. and O. Nordhaug (1996), 'Optimal Investment Committee Size', Journal of Portfolio Management, Vol. 22, No. 2, pp. 87-94.

Gorton, G. and F. A. Schmid (2000), 'Universal Banking and the Performance of German Firms', Journal of Political Economy, Vol. 58, No. 1-2, pp. 29-80.

- (2004), 'Capital, Labor, and the Firm: A Study of German Codetermination', Journal of the European Economic Association, Vol. 2, No. 5, pp. 863-905.

Gow, I. D., G. Ormazabal and D. Taylor (2010), 'Correcting for Cross-Sectional and Time-Series Dependence in Accounting Research', Accounting Review, Vol. 85, pp. 483-512.

Greene, W. H. (2003), Econometric Analysis (5th ed., New York: Prentice Hall).

Hansmann, H. (1996), The Ownership of Enterprise (Cambridge, Mass.: Harvard University Press).

Hawawini, G. and D. B. Keim (2000), 'The Cross-Section of Common Stock Returns: A Synthesis of the Evidence and Explanations', in W. T. Ziemba and D. B. Keim (eds.), Security Market Imperfections in World Equity Markets, Chapter 2 (Cambridge, UK: Cambridge University Press), pp. 3-43.

Hermalin, B. E. and M. S. Weisbach (1991), 'The Effect of Board Composition and Direct Incentives on Firm Performance', Financial Management, Vol. 21, No. 4, pp. 101-12.

_ (1998), 'Endogenously Chosen Boards of Directors and their Monitoring of the CEO', American Economic Review, Vol. 88, No. 1, pp. 96-118.

$-12003)$, 'Boards of Directors as an Endogenously Determined Institution: A Survey of the Economic Literature', Economic Policy Review, Vol. 9, No. 1, pp. 7-26.

- (2006), 'A Framework for Assessing Corporate Governance Reform', NBER Working Papers 12050 (National Bureau of Economic Research, Inc.).

Hertig, G. (2005), 'On-Going Board Reforms: One-Size-Fits-All and Regulatory Capture', Oxford Review of Economic Policy, Vol. 21, No. 2, pp. 269-82.

Hopt, K. J. (1998), 'The German Two-Tier Board: Experience, Theories, Reform', see Hopt et al., 1998, Chapter 4(a), pp. 227-58.

- - H. Kanda, M. J. Roe, E. Wymeersch and S. Prigge (eds.) (1998), Comparative Corporate Governance: The State of the Art and Emerging Research (Oxford, UK: Oxford University Press).

Hsiao, C. (2003), Analysis of Panel Data (2nd ed., Cambridge, UK: Cambridge University Press).

Kennedy, P. (2008), A Guide to Econometrics (6th ed., Oxford, UK: Blackwell Publishing).

Klein, A. (1998), 'Firm Performance and Board Committee Structure', Journal of Law $\mathcal{E}$ Economics, Vol. 46, pp. 275-303.

La Porta, R., F. L. de Silanes, A. Shleifer and R. Vishny (2000), 'Investor Protection and Corporate Governance', Journal of Political Economy, Vol. 58, No. 1-2, pp. 3-28. 
Larcker, D. and T. O. Rusticus (2007), 'Endogeneity and Empirical Accounting Research', European Accounting Review, Vol. 16, No. 1, pp. 207-15.

- and T. O. Rusticus (2010), 'On the Use of Instrumental Variables in Accounting Research', Journal of Accounting and Economics, Vol. 49, No. 3, pp. 186-205.

Lasfer, M. A. (2006), 'The Interrelationship between Managerial Ownership and Board Structure', Journal of Business Finance $\mathcal{E}$ 'Accounting, Vol. 33, No. 7, pp. 1006-33.

McConnell, J. and H. Servaes (1990), 'Additional Evidence on Equity Ownership and Corporate Value', Journal of Financial Economics, Vol. 27, pp. 595-612.

Nickell, S. J. (1981), 'Biases in Dynamic Models with Fixed Effects', Econometrica, Vol. 16, No. 49, pp. 1417-26.

Perry, T. and U. C. Peyer (2005), 'Board Seat Accumulation by Executives: A Shareholder's Perspective', Journal of Finance, Vol. 60, No. 4, pp. 2083-123.

Petersen, M. A. (2009), 'Estimating Standard Errors in Finance Panel Data Sets: Comparing Approaches', Review of Financial Studies, Vol. 22, pp. 435-80.

Raheja, C. G. (2005), 'Determinants of Board Size and Composition: A Theory of Corporate Boards', Journal of Financial and Quantitative Analysis, Vol. 40, No. 2, pp. 283-306.

Schmid, F. A. and F. Seger (1998), 'Arbeitnehmermitbestimmung, Allokation von Entscheidungsrechten und Shareholder Value', Zeitschrift fur Betriebswirtschaft, Vol. 68, No. 5, pp. $453-73$.

Shleifer, A. and R. W. Vishny (1986), 'Large Shareholders and Corporate Control', Journal of Political Economy, Vol. 94, No. 3, pp. 461-86.

Shrader, C. B., V. B. Blackburn and P. Iles (1997), 'Women in Management and Firm Financial Performance: An Exploratory Study', Journal of Managerial Issues, Vol. 9, No. 3, pp. 355-72.

Smith, N., V. Smith and M. Verner (2006), 'Do Women in Top Management Affect Firm Performance? A Panel Study of 2300 Danish Firms', International Journal of Productivity and Performance Management, Vol. 55, No. 7, pp. 569-93.

Wasserman, S. and K. Faust (1994), Social Network Analysis: Methods and Applications (Cambridge, UK: Cambridge University Press).

Williamson, O. E. (1996), The Mechanisms of Governance (Oxford, UK: Oxford University Press).

Wooldridge, J. M. (2002), Econometric Analysis of Cross Section and Panel Data (Cambridge, Mass.: The MIT Press).

Wymeersch, E. (1998), 'A Status Report on Corporate Governance Rules and Practices in Some Continental European States', see Hopt et al., 1998, Chapter 12(d), pp. 1045-200.

Yermack, D. (1996), 'Higher Market Valuation of Companies with a Small Board of Directors', Journal of Financial Economics, Vol. 40, pp. 185-212. 